\title{
A clinical study of ectopic pregnancy
}

\section{Shanti Sri Asuri*, Kalpana P.}

Department of Obstetrics and Gynaecology, Princess Esra Hospital, Deccan College of Medical Sciences, Hyderabad, Telangana, India

Received: 06 October 2016

Accepted: 12 October 2016

\section{*Correspondence:}

Dr. Shanti Sri Asuri,

E-mail: shantisrinivas@gmail.com

Copyright: (c) the author(s), publisher and licensee Medip Academy. This is an open-access article distributed under the terms of the Creative Commons Attribution Non-Commercial License, which permits unrestricted non-commercial use, distribution, and reproduction in any medium, provided the original work is properly cited.

\section{ABSTRACT}

Background: The diagnosis of an ectopic pregnancy is usually unexpected and is often emotionally traumatic. Many women may have only recently discovered they were pregnant when they receive the diagnosis. Some women diagnosed with an ectopic pregnancy do not even know they are pregnant and suddenly must think about the possibility of major surgery or medical treatment. The present study involves a study on all the cases of ectopic pregnancy who were admitted to the Princess Esra Hospital, Deccan College of medical sciences, Hyderabad during November 2014 to October 2015. The objectives of the study were, 1. To know the age group, gravidity, parity and the risk factors with respect to the ectopic pregnancy. 2. To know the clinical presentation of the ectopic pregnancy. 3. To know the outcome of the ectopic pregnancy.

Methods: A total of 62 patients who were diagnosed as ectopic pregnancy cases were analyzed. All these cases were analyzed after applying the inclusion and exclusion criteria with respect to the 1. History. 2. Clinical presentation. 3. Investigations. 4. Treatment.

Results: The incidence of the ectopic pregnancy in the present study was 1:380 pregnancies. A majority of the cases were multigravidas. Pain abdomen, amenorrhoea and bleeding per vagina in at least $50 \%$ of the cases. The tube was ruptured in almost $80 \%$ of the cases and there was a haemoperitoneum. Almost all the patients had intraoperative and/ or postoperative blood transfusions. There was no significant post operative morbidity in these cases.

Conclusions: The early diagnosis of an ectopic pregnancy is one of the greatest challenges for a physician. It requires a high index of suspicion to diagnose an ectopic pregnancy. The importance of an early diagnosis lies in the fact that the lady can be offered a conservative line of management which can definitely have a beneficial effect on her reproductive career.

Keywords: Ectopic, Laparotomy, Salpingectomy

\section{INTRODUCTION}

Lawson Tait, the father of gynaecologic surgery, reported the first successful operation for ectopic pregnancy in 1883. His main difficulty lay in establishing the diagnosis. ${ }^{1}$ Until a little more than decade ago, little change had occurred in the diagnosis and management of ectopic pregnancy. The clinical use of sensitive pregnancy testing, transvaginal ultrasonography and diagnostic laparoscopy has had a major impact on the preoperative diagnosis of this condition. An ectopic pregnancy is one in which the fertilized ovum is implanted in a site other than the uterine cavity. ${ }^{2}$ Incidence of ectopic pregnancy is 1:160 deliveries. ${ }^{3}$ Clinical presentation is variable from acute to chronic presentation. The rate of ectopic rupture has declined, and the option of conservative surgical management of an unruptured fallopian tube is now a viable alternative. An ectopic pregnancy is a challenge for the obstetrician and gynaecologist due to its bizarre clinical presentation. The 
diagnosis of ectopic pregnancy is complicated by wide spectrum of clinical presentations, from asymptomatic cases to acute abdomen, and hemodynamic shock. ${ }^{4}$ Ectopic pregnancy is one of the commonest causes of first trimester maternal death in developed countries and only follows induced abortion in sub-Saharan Africa. ${ }^{5}$ This study is aimed to find the incidence of ectopic pregnancy in the study population and to evaluate the symptomatology and clinical presentation and to analyze the morbidity mortality occurring in these patients.

\section{METHODS}

This was a retrospective study of ectopic pregnancies at the Princess Esra Hospital, Deccan College of medical sciences, Hyderabad during November 2014 to October 2015. All patients with a history suggestive of ectopic pregnancy and in whom diagnosis was confirmed by clinical acumen, ultrasound or direct observation at laparotomy are included in the study The case sheets of the patients with ectopic pregnancy were traced through the labor ward registers and operation theatre registers. Information regarding the total number of deliveries in the study period, details of demographic characteristics, clinical symptoms and signs, diagnostic tools used, treatment, risk factors for the ectopic pregnancy as well as associated morbidity and mortality were obtained. All the surgeries were done by laparotomy and spinal/general anesthesia was used in all the cases. This retrospective analysis was done to determine the incidence, clinical features, risk factors, treatment and morbidity and mortality associated with ectopic pregnancy in a tertiary care teaching hospital.

\section{Inclusion criteria}

The women who were diagnosed as ectopic pregnancy cases, who were in the reproductive age group of 15-44 years.

\section{Exclusion criteria}

There are no exclusion criteria.

\section{RESULTS}

This study was undertaken at the Princess Esra Hospital, Deccan College of medical sciences, Hyderabad during November 2014 to October 2015. The incidence of ectopic pregnancy in the present study was 1:380 deliveries.

\section{Incidence of age}

A majority of the patients $(72 \%)$ belonged to the $20-30$ years age group with a mean age of 24 years, the youngest was 16 years old and the oldest was 44 years old.

\section{Gravidity and parity}

$3 \%$ were unmarried, $24 \%$ were nulliparas, $11 \%$ were primiparous and the rest $(62 \%)$ were multiparous.

\section{Risk factors}

Of the various risk factors, PID is seen in $25.80 \%, 8$ patients had history of sterilization, 2 patients had history of dilatation and curettage, 4 patients had repeat ectopic History suggestive of PID was taken when all three symptoms, i.e. abdominal pain, vaginal discharge and fever were present, which was found in 16 women. History of previous abortion is suggestive of tubal damage due to ascending infection, was seen as a contributing factor in 3 cases.

Table 1: Risk factors for ectopic gestation.

\begin{tabular}{|lll|}
\hline Risk factors & Number of cases & Percentage \\
\hline $\begin{array}{l}\text { Infertility (primary } \\
\text { and secondary) }\end{array}$ & 3 & $4.83 \%$ \\
\hline Prior tubal ligation & 8 & $12.9 \%$ \\
\hline History of PID & 16 & $25.8 \%$ \\
\hline Previous D\&C/D\&E & 5 & $8.06 \%$ \\
\hline Previous ectopic & 4 & $6.45 \%$ \\
\hline H/o appendicectomy & 1 & $1.61 \%$ \\
\hline Previous C-section & 4 & $6.45 \%$ \\
\hline No risk factors & 20 & $32.25 \%$ \\
\hline $\begin{array}{l}\text { Irregular use of } \\
\text { COCP }\end{array}$ & 1 & $1.61 \%$ \\
\hline
\end{tabular}

A majority of the cases presented with pain in the abdomen (80.2\% of cases); amenorrhoea (70\%) and spotting (46\%). Around $42.8 \%$ of the cases were brought in a state of shock. Tenderness on cervical movement was present in $70 \%$ of the cases and masses in the fornices were present in $68.3 \%$ of the cases. The urinary pregnancy test was positive in $92 \%$ of the cases and culdocentesis was positive only in $22.58 \%$ of the cases. Ultrasound revealed a ruptured ectopic pregnancy in $46 \%$ of the cases; an unruptured pregnancy in $6 \%$ of the cases and an adnexal heterogenous mass in $42.5 \%$ of the cases. In $78 \%$ of the cases, significant free fluid was noted in the Pouch of Douglas. A majority of the cases were ampullary pregnancies (70.96\%). Interstitial/cornual pregnancy was seen in $2 \%$ of the cases and $23.8 \%$ of the cases were isthmal pregnancies. $82.3 \%$ showed a ruptured ectopic pregnancy on laparotomy. Tubal abortion and an unruptured ectopic pregnancy were seen in 6 and 3 cases respectively.

93.5\% of the cases showed a haemoperitoneum on laparotomy. The most common procedure which was done was salpingectomy in $54.8 \%$ of the cases. In all cases of post sterilization ectopic gestation, salpingectomy of the affected tube and relegation of the other tube were undertaken to avoid recurrence of ectopic pregnancy on the other side. 
Table 2: Surgical treatment in cases of ectopic gestation.

\begin{tabular}{|lll|}
\hline $\begin{array}{l}\text { Operative procedure } \\
\text { Unilateral } \\
\text { salpingectomy }\end{array}$ & 34 & $54.8 \%$ \\
\hline $\begin{array}{l}\text { Unilateral salpingo- } \\
\text { ovariotomy }\end{array}$ & 4 & $6.45 \%$ \\
\hline $\begin{array}{l}\text { Unilateral } \\
\text { salpingectomy+ligatio } \\
\text { n of tube on } \\
\text { contralateral side }\end{array}$ & 12 & $19.35 \%$ \\
\hline $\begin{array}{l}\text { Bilateral } \\
\text { salpingectomy }\end{array}$ & 8 & $12.9 \%$ \\
\hline Salpingostomy & 3 & $4.83 \%$ \\
\hline $\begin{array}{l}\text { TAH+bilateral } \\
\text { salpingectomy }\end{array}$ & 1 & $1.61 \%$ \\
\hline
\end{tabular}

In one case of cervical ectopic pregnancy, total abdominal hysterectomy was done. Most of these cases (52) had blood transfusions intra-operatively and postoperatively. The postoperative period was uneventful, except one case which developed postoperative sub-acute intestinal obstruction which was reopened on $10^{\text {th }}$ POD and was found to have an inflammed Meckels diverticulum on relaparotomy.

\section{DISCUSSION}

\section{Incidence}

The incidence of ectopic pregnancy has increased since the last 20 years. The incidence in this present study was $1: 380$ deliveries.

\section{Risk factors and ectopic pregnancy}

There are a number of risk factors that lead to tubal damage and dysfunction predisposing to ectopic pregnancy. While there is an overlap, these can be generalized as mechanical and functional factors. Mechanical factors like salpingitis, prior tubal surgery, prior ectopic pregnancy, prevents or retard the passage of the fertilized ovum into the uterine cavity. Functional factors like changes in serum level of estrogens and progesterone delay passage of the fertilized ovum into the uterine cavity by altering the tubal motility. ${ }^{11}$

\section{Previous abortions and $D$ and $C$}

In the current study the incidence of ectopic following curettage was $8.06 \%$.

\section{PID and ectopic pregnancy}

In the current study incidence of ectopic with a history of PID was $25.8 \%$, which is similar to that in Savitha Devi's study- $25 \%$, in Rose et al, study the incidence of ectopic with history of PID was $34.4 \%$.

\section{History of infertility}

In the current study- $4.83 \%$ In March Banks' study$2.9 \%$, in Savitha Devi's study- $48.07 \%$, in Rose et al, study- $15.1 \%$ In Arora et al, study- 11.2\%, in Mitra et al, study- $55.2 \%$.

\section{Previous ectopic}

In the present study the incidence is slightly higher i.e. $6.45 \%$, in Rashmi et al, study $2012-2.7 \%$, in Rose et al, study- $3.2 \%$. This is because tubal disease is nearly always bilateral and because there is a strong tendency for ectopic pregnancy to occur first on one side and then later on the other side. ${ }^{6}$ The most important risk factor for ectopic pregnancy is a history of a previous ectopic gestation. This event confers a 10-fold increase in the likelihood of another ectopic pregnancy. ${ }^{7,8}$

\section{Clinical symptoms}

The classical findings of pain in the abdomen, amenorrhoea and vaginal bleeding are not seen in all the cases. This is because the clinical picture is dependent on several factors, the most important factor being the time which is taken for a disturbance to occur in the ectopic pregnancy. The more extensive and rapid the disturbance is the clearer is the clinical picture. On the other hand, an undisturbed unruptured ectopic pregnancy is more likely to be missed unless it is recognized by ultrasonography.

\section{Physical examination}

In the present study, most of the cases $(40.5 \%)$ presented with shock as compared to those in other studies. This was because a majority of the cases $(78.37 \%)$ presented or referred with a ruptured ectopic pregnancy. Pallor was a significant finding which was seen in almost $70-80 \%$ of the cases of ectopic pregnancies. Thus, clinical evaluation gives an important clue to the diagnosis. In the present study, as most of the cases were suggestive of a ruptured ectopic pregnancy, they were taken up for laparotomy and salpingo-oophorectomy / salpingectomy (67.6\%).

\section{CONCLUSION}

Ectopic pregnancy is a nightmare for the obstetrician. High degree of suspicion and early diagnosis is the key to successful management. The dictum should be to have a high degree of suspicion in a woman in reproductive age group with pain abdomen or bleeding PV or when she comes in shock irrespective of tubal ligation as in many cases there may be not even a history of amenorrhea. PID is considered a major etiologic factor in ectopic pregnancy. Because the incidence of PID has risen dramatically over the past two decades, it has been suggested that part of the increased incidence of ectopic gestation can be attributed to this disease. 
Increasing awareness among sexually active women and men regarding safe sexual practices and contraception decrease abortions and reduces the risk of ectopic pregnancy. All high risk women should be screened at the earliest with serum $\beta$-hCG and TVS. The impact on future fertility can be improved by focusing on primary prevention and early diagnosis before rupture.

Funding: No funding sources

Conflict of interest: None declared

Ethical approval: The study was approved by the Institutional Ethics Committee

\section{REFERENCES}

1. Tait RL. Five cases of extrauterine pregnancy operated upon at the time of pregnancy. Br Med J. $1884 ; 1: 1250$.

2. Tindall VR. Ectopic pregnancy. In: Jeffcoate's Principles of Gynaecology, $7^{\text {th }}$ edition, Oxford, Butterworth-heinemann Ltd.; 1996:212-225.

3. Friyal Omer Mohamed Nour University of Khartoum, Sudan, Geneva-Ectopic pregnancy Incidence, morbidity and mortality.
4. Berek JS, Berek DL. Berek and Novak's Gynecology. 15th ed. USA: Lippincott, Williams and Wilkins, A Wolters Kluwer Business; 2012:627.

5. Thonneau P, Hijazi Y, Goyaux N, Calvez T, Keita N. Ectopic pregnancy in Conakry, Guinea. Bull World Health Organ. 2002;80:365-70.

6. Comprehensive Gynaecology, $3^{\text {rd }}$ edition. Missouri, St Louis: Mosby; 1997:432.

7. DeCherney A, Minkin MJ, Spangler S: Contemporary management of ectopic pregnancy. J Reprod Med. 1981;26:519.

8. Douglas ES, Singleton HM, Crist T: Surgical management of tubal pregnancy: Effect on subsequent fertility. South Med J. 1969;62:954.

9. Cunningham FG, Gant NF, Leveno KJ, Gilstrap LC, Hauth JC, Wenstrom KD. Ectopic pregnancy. Williams Obstetrics. $21^{\text {st }}$ ed. New York: McGrawHill; 2001:883.

Cite this article as: Asuri SS, Kalpana P. A clinical study of ectopic pregnancy. Int J Reprod Contracept Obstet Gynecol 2016;5:3750-3. 